\title{
1. INTRODUCTION: PRACTICE THEORY AND THE THEORY OF PRACTICE ARCHITECTURES
}

\author{
Kathleen Mahon, Stephen Kemmis, Susanne Francisco, and Annemaree Lloyd
}

\begin{abstract}
This chapter introduces the theory of practice architectures and locates it within the theoretical landscape of practice theory. It highlights what is distinctive about the theory as a practice theory, and discusses its affordances as a theoretical, analytical, and transformational resource for practitioners and researchers. We argue that, to create new possibilities for practice in our disciplines and professions, and/or to challenge unsustainable or untoward practices in education and professional practice more broadly, our current practices must be interrogated. The theory of practice architectures can inform such interrogative work. This chapter provides a foundation for the case chapters in this book which variously illustrate the kinds of insights yielded by exploring education and professional practice through the lens of practice architectures.
\end{abstract}

Practitioners all over the world frequently ask themselves as they go about their work, how can we do this better? How can we practice in ways that are more sustainable and just? What should we do differently to create new possibilities and opportunities? Questions about how to become a better practitioner, to practice in ways that are more sustainable, or to create new possibilities and opportunities, are an important part of the daily dialogue and reflections of practitioners. They are important questions asked in a world of professional practice made more complex by the highly technologised, globalised, and governed society of the $21 \mathrm{st}$ century. These questions are particularly important for education and our educational institutions, where justice and possibilities for human flourishing are sometimes undermined by, for example, economic imperatives, competing demands and external pressures, and harmful/unsustainable ideologies. The task of addressing such questions and transforming education and professional practice is a crucial ongoing responsibility and challenge for practitioners, researchers, and practitioner researchers alike. It is a task that requires many things, not least resources that allow us to understand our respective professional realities; to examine what shapes, sustains, and transforms our realities; and to respond appropriately, or 'speak back' to constraining and unsustainable conditions, whether we are experienced practitioners, professional leaders, practitioner educators, aspiring professionals, researchers, or policy makers.

The theory of practice architectures is such a resource. It is at once a theoretical resource for understanding education and professional practice; an analytical (or methodological) resource for revealing the ways practices are enabled and constrained by the conditions under which they occur (and especially, we shall argue, the practice architectures that make them possible and hold them in place); and a transformational resource for finding ways to change education and professional practice, where current practices and conditions are untoward - that is, they are unreasonable, unproductive or unsustainable, or the cause of suffering or injustice. In general, this book argues, the transformational aim of research using the theory of practice architectures emerges in research for praxis, both in the personal sense of helping participants in, or responding to, untoward situations decide how they might act morally, for the good of the persons concerned, and also politically, in the interests of the good for humankind.

So what is the theory of practice architectures? The theory of practice architectures is a contemporary account of social reality that focusses on practice. It is a practice theory (Schatzki, 2001), a term which denotes a broad church of social and cultural theories related 
to each other by virtue of their fundamental concern with practice (Green, 2009; Nicolini, 2013). As a practice theory, the theory of practice architectures shares common ground with other practice theories. However, in some respects it has emerged through a process of problematising practice theory and offers a distinctive ontological view of what practice is, how practices are shaped and mediated, and how practices relate to each other. As we shall argue, the theory makes a unique contribution to the practice theory debate through the ways that it politicises practice, humanises practice, theorises relationships between practices, is ontologically oriented, and offers insights pertaining to education. This contribution is important given the take up of practice theory in recent decades by those hoping to further our understanding of, and create transformational possibilities in, education and professional practice more broadly.

Since the theory was first articulated by Stephen Kemmis and Peter Grootenboer (Kemmis \& Grootenboer, 2008) it has continued to evolve. It has undergone several iterations as Kemmis and Grootenboer and their colleagues have continued to engage with it in their research work, and in their everyday practice and encounters with other scholars and theoretical resources (see Kemmis, Edwards-Groves, Wilkinson, \& Hardy, 2012; Kemmis \& Heikkinen, 2012; Kemmis, Heikkinen, Aspfors, Fransson, \& Edwards-Groves, 2014; Kemmis, McTaggart, \& Nixon, 2014; Kemmis \& Mutton, 2012; Kemmis, Wilkinson, Edwards-Groves, Hardy, Grootenboer, \& Bristol, 2014; Ronnerman \& Kemmis, in press). The ways in which the theory is being put to work in social inquiry has also been evolving as an increasing number of researchers are using the theory as a lens for examining practices in an expanding range of fields and disciplines. This includes vocational education (e.g., Brennan Kemmis \& Green, 2013); nursing (e.g., Hopwood, Fowler, Lee, Rossitera, \& Bigsby, 2013); teacher mentoring (e.g., Kemmis, Heikkinen et al., 2014); pre-service teacher education (e.g., Hemmings, Kemmis, \& Reupert, 2013; Sjolie, 2014); higher education (e.g., Mahon, 2014; Taylor, 2012); early childhood education (Salamon, Sumsion, Press, \& Harrison, 2015); educational leadership (e.g., Bristol, 2014; Edwards-Groves \& Rönnerman, 2012; Wilkinson, Olin, Lund, Ahlberg, \& Nyvaller, 2010; Salo, Nyland, \& Stjernstrøm, 2014); and professional learning in universities (e.g., Green, Hibbons, Houghton, \& Ruutz, 2013; Hardy, 2010a, 2010b). Of course, a variety of new studies exploring the theory are presented in this book.

In this chapter, we introduce the theory of practice architectures, and highlight what is distinctive and significant about the theory. We also discuss some of the analytical possibilities and transformational opportunities afforded by the theory. It is our hope that the discussion will be informative for those working with this theory, or contemplating doing so, whether for theoretical purposes, for empirical purposes, or for the purposes of practitioner reflexivity and self-inquiry, and/or changing education and professional practice.

The first part of the chapter sketches the theoretical landscape of practice theory more generally. This provides a backdrop for our subsequent explanation of the theory of practice architectures. There are a number of works that introduce, trace the history of, and/or provide in-depth discussions of, practice theory (e.g., Hager, 2012; Nicolini, 2013; Reckwitz, 2002; Schatzki 2001, 2012; Shove, Pantzar, \& Watson, 2012 ${ }^{1}$ ). In this chapter we defer to these

\footnotetext{
${ }^{1}$ Readers are encouraged to consult this work for a more comprehensive explication of practice theory. Nicolini (2013) has explored in detail the contribution of various theoretical and/or methodological traditions including cultural-historical activity theory (CHAT), ethnomethodology, actor network theory, discourse analysis, and traditions related to the work of Giddens, Bourdieu, Wittgenstein, Heidegger, and Schatzki. Reckwitz (2002), in contrast, has located practice theory in relation to other cultural theories (mentalism, culturalism, and intersubjectivism). Schatzki (2001) provided an historical account of practice theory as an introduction to an edited collection of chapters exemplifying his notion of a 'practice turn'. Other authors have provided a brief history of practice theory as a way of locating their own philosophical/empirical work, shedding light on, or critiquing, the
} 
previous accounts and provide only a brief introduction to the key themes, dimensions and features of practice theory, focussing on aspects that are most salient for our discussion of the theory of practice architectures in the second and third parts of the chapter. The second part of the chapter explains the theory of practice architectures in its most recent form. Some of the key concepts and terms are given particular attention in this discussion, building on what has been written about the theory elsewhere (e.g., Kemmis \& Grootenboer, 2008; Kemmis, Wilkinson et al., 2014). An explanation of the theory of 'ecologies of practices' (Kemmis et al., 2012) is included. The aim of this discussion is to lay the theoretical groundwork for the case chapters in this book. The third part of the chapter locates the theory of practice architectures within the practice theory landscape and outlines some key affordances of the theory. As part of the discussion we highlight points of convergence and divergence with other practice theories, and discuss ideas that the theory reacts against. We view such a contextualisation of the theory as key to a critical reading, and to critical use, of the theory. (Chapter 13 provides a more comprehensive discussion of the evolution of the theory of practice architectures in relation to other practice and social theories).

We close the chapter with an explanation of how the book is organised. We introduce some of the themes that shape the book's unfolding, and invite readers to join us on a journey into the work and ponderings of researchers exploring education and professional practice in a variety of settings through the lens of the theory practice architectures.

Before proceeding, we should say a word about what we mean by 'professional practice'. We regard professional practice as socially- and ethically-informed practice in various professional (and occupational) fields; it is 'professional' not only by virtue of being linked to specific occupations, but also because it is conducted in the manner that, in ordinary language, we describe as 'professional'. In what follows, we explore 'practice' in more detail. We should also say that chapters in this volume generally consider various kinds of 'educational' practice. This focus reflects the research and affiliations of the authors represented in the volume. We nevertheless believe that much of what is said about professional practice in the volume is relevant to practice in other fields.

\section{The Theoretical Landscape of Practice Theory}

A 'practice turn' (Schatzki, 2001) has been shaping, or is being experienced, in many areas of the social sciences. This turn represents a "prioritisation of practices" (Schatzki, 2001, p. 11) in endeavours to understand and critique social reality. Practice theory provides lenses which make examination of practices possible, and in doing so enables useful accounts of how practices happen, how they are mediated, and their role in the constitution of social life.

Although the theories encompassed in the term practice theory are multiple and diverse (Nicolini, 2013; Schatzki, 2001), as Nicolini (2013) noted, they converge in terms of their treatment of social practices as a "starting point for theorizing human affairs" (p. 162). Commonly located under a practice theory umbrella is the work of Garfinkel (1967), Giddens (1976; 1979; 1984), Foucault (1976, 1980), Bourdieu (1977; 1990), MacIntyre (1981), Taylor (1985), Lave and Wenger (1991), Schatzki (1996; 2001; 2002; 2012), Bourdieu and Wacquant (1992), and Latour (2005). More recent practice theory work has been done by authors such as Gherardi (2006, 2009), Hager, Lee, and Reich (2012), Lloyd (2010), Green and Hopwood (2015), Reckwitz (2002), and, as we highlight in this chapter, Kemmis and colleagues.

contributions and relevance of practice theory to their fields (e.g., Feldman \& Orlikowski, 2011; Corradi, Gherardi, \& Verzelloni, 2010); and/or contextualising their arguments (Green, 2009; Shove et al., 2012). 
It is possible to point to some common features and assumptions amongst the various practice theories. Practice theories are marked by an "interest in the 'everyday' and 'lifeworld'" (Reckwitz, 2002, p. 244) and share a basic tenet that practices are situated, social, and relational. Many practice theorists subscribe to the view that inherent within practices are patterns of activity and understandings that are critical in, and shape, human life (Reckwitz, 2002; Schatzki, 2012). Practice theorists generally recognise the importance of material things and materiality as well as communication and text/symbols in the constitution of practices (Reckwitz, 2002). They also reject dualisms (Bourdieu \& Wacquant, 1992; Feldman \& Orlikowski, 2011; Reckwitz, 2002) - such as mind and body, structure and agency, and cognition and action - and recognise non-propositional knowledge as not only important, but also embodied and enacted within/through practice (Schatzki, 2002). While on the one hand they assert that we know more than we can say, they also assert that what we do typically means more than we know. Crucially, practices tend to be favoured by practice theorists - for instance, over individuals or mental structures and processes (Reckwitz, 2002) - as the primary subject of analysis for examining social relations (Nicolini, 2013; Shove et al., 2012) $)^{2}$.

Despite these general commonalities, there is no unified theory of practice (Corradi et al., 2010, p. 267) or practice approach (Schatzki, 2001). Indeed, the theoretical landscape of practice theory is a complex and unsettled one (Feldman \& Orlikowski, 2011), partly because practice theory has been informed by several evolving intellectual traditions. Practice theories vary widely in terms of how practice is defined and, relatedly, what counts as practice (Nicolini, 2013). Differences also exist in relation to what is foregrounded in accounts of practice. Some theories draw attention to discursive dimensions of practices, while other theories emphasise power and the political, moral dimensions and consequences of practice, or historical occurrences ${ }^{3}$.

The extent to which practice theorists take a more ontological or epistemological approach to practices is another point of difference between practice theories. When practices are treated ontologically, practice theorists attend to the specific content and conduct of practice, its organisation in space and time, the arrangements that make it possible and hold it in place, its transformation, and the sites in which it happens (e.g., Schatzki, 2002) ${ }^{4}$.

Schatzki's (2002) site ontology exemplifies this well through attention paid to practice as the "primary generic social thing" (2001, p. 1), and a focus on enactment of social life as it transpires through the nexus of "practice and material arrangements" (Schatzki, 2005, p. 471). When practices are treated epistemologically, practice theorists focus more systematically on, for instance, practical knowledge and learning/knowing processes, (i.e., what and how people come to know in a practice). Lave and Wenger's (1991) notions of 'legitimate peripheral participation' and 'situated learning' are illustrative of such an orientation. Gherardi and Nicolini's (2000a; 2000b) work on how knowledge emerges and/or is constructed in relation to workplace safety practices is a further example. Some practice theories address both epistemological and ontological questions, seeing practices as both the locus of learning and knowing (Fenwick, 2012; Sjølie, 2014) and constitutive of social life.

\footnotetext{
${ }^{2}$ Mental processes are not ignored. Rather they are treated as embedded "in a complex of doings" (Reckwitz, 2002, p. 258).

${ }^{3}$ For examples of some of these differences, see Nicolini's (2013) comparison of MacIntyre and Wenger (p. 9-10) or Kemmis's (2010b) table outlining the key features of practice as identified by various intellectual traditions.

${ }^{4}$ The ontological nature of practice theories has been acknowledged by Nicolini (2013), although his own work has a distinctive epistemological focus (see for example, Gherardi \& Nicolini, 2000a, 2000b; Nicolini, Gherardi, \& Yanow, 2003).
} 
More is said about this in our discussion of the theory of practice architectures later in this chapter.

Another point of divergence is the status ascribed, or attention drawn, to materiality or material artefacts (e.g., tools, texts, technologies, furniture, office spaces, diseases, rain, signs) in shaping and constituting practices. Some practice theories, for instance, reflect a perspective best described as 'sociomaterial' - one which embraces a range of perspectives, but that generally foregrounds materiality and positions material artefacts and activity as enmeshed or entangled (Hodder, 2012) rather than as discrete elements that are co-constituted (Orlikowski, 2010). Some theories, such as actor network theory go so far as to de-centre human agency and describe the agency of non-human elements (see Latour, 1996, 2005). This contrasts with perspectives that stress the role of non-human entities in practice without ascribing them status as agents (e.g., Schatzki, 2002).

The differences between practice theories stem largely from their roots in varying scholarly traditions (Nicolini, 2013) and the influence of a range of theorists and philosophers who are not necessarily regarded as practice theorists themselves. Aristotle, for instance, has been influential in terms of his conceptualisation of praxis (as distinct from epistēme and technē), and attention to the moral dimensions of what we now call 'practice'. Marx left an indelible mark on practice theory, materialising Hegel's idealist view of progress through history by showing how material practices (like divisions of activities between workers and owners) formed and secured patterns of social relationships (like class divisions in a society). There are traces of Marx's work in practice theories that highlight the materiality of practice (Shove et al., 2012), and the 'history making' dimension of practice.

Several contemporary writers have also paid homage to Wittgenstein and Heidegger (see Feldman \& Orlikowski, 2011; Green, 2009; Nicolini, 2013; Reckwitz, 2002; Schatzki, 2002; Shove et al., 2012), and to pragmatists such as Dewey. Wittgenstein's and Heidegger's work have been particularly influential in relation to the notion of intelligibility. Wittgenstein (1957), while not specifically attending to an account of practice, recognised that human activity is rendered meaningful within social practices. He suggested that practice acts as the site and source of intelligibility and understanding, structuring human action. Heidegger (1962) meanwhile provided an influential account of Dasein, or being in the world, and recognised practice as a site and source of meaning through action and reflexivity. Dewey, in contrast, has been acknowledged for his attention to embodied knowledge and experience in the transformation and continuity of habits and routines (see Green, 2009; Schatzki, 2002; Shove et al., 2012).

Contemporary practice theory has also been influenced by writers who have provided more explicit accounts of practice relative to those just mentioned. Among these are Garfinkel (1967), Bourdieu (1977; 1990), Foucault (1976; 1980), Giddens (1979, 1984), MacIntyre (1981), Taylor (1985), and Engeström (1999). More is said about some of their contributions in Chapter 13 of this book.

The ideas about practice emerging from the work of such theorists and philosophers have been challenged and extended in more recent writing about practice theory, notably in the work of Schatzki (2002), with his ontological perspective of practices as 'sites of the social'. Other contemporary practice theorists making influential contributions to the field of practice theory include Reckwitz, Lave and Wenger, Gherardi, and Nicolini. Reckwitz (2002) introduced the idea that individual agents are "carriers" of a practice (p. 252) and Lave and Wenger (1991) have introduced the notion of "communities of practice" (p. 49). Gherardi (2006) and Nicolini's (2011) work on relationships between knowing (or knowledge) and practice has also provided important contributions, for instance, in relation to the building industry in Gherardi's case, and in relation to telemedicine in Nicolini's case. 
Practice theories are now being used as lenses for examining social life and social phenomena in an increasing range of fields, some of which overlap, including education (e.g., Kemmis, Wilkinson et al., 2014); organisational studies (e.g., Feldman \& Orlikowski, 2011; Gherardi, 2006, 2009; Nicolini, 2011; Price, Sheeres, \& Boud, 2009), information studies (e.g., Lloyd, 2010), health services (e.g., Hopwood, 2014), consumer culture (e.g., Butler, Parkhill, \& Pidgeon, 2014; Hargreaves, 2011), and professional practice and learning (see Fenwick, 2012; Green 2009; Green \& Hopwood, 2015; Hager, Lee, \& Reich, 2012). This array of fields may be contributing to the diversity in contemporary practice theory and approaches to practice theory, since each field or discipline potentially yields its own contextspecific theoretical insights. The growing body of work to which these and many other authors are contributing is helping to shed light on a multitude of issues from the use of technology in the workplace (e.g., Orlikowski, 2007) to knowing in telemedicine practice (e.g., Nicolini, 2011); from group learning (Hager, 2013) to partnership and accountability in health services (e.g., Hopwood, 2014); and from energy consumption in households (e.g., Butler, Parkhill, \& Pidgeon, 2014) to transforming education for the twenty first century (Kemmis, Wilkinson et al., 2014).

The theory of practice architectures is both a practice theory and a response to the field of practice theory that we have briefly mapped out here. We elaborate on how this is so in the last part of this chapter. At this point, a detailed explanation of the theory is warranted, and it is to such an explanation that we now turn.

\section{The Theory of Practice Architectures: A Site Ontological Perspective on Practices}

The theory of practice architectures is an account of what practices are composed of and how practices shape and are shaped by the arrangements with which they are enmeshed in a site of practice. A practice is understood as a socially established cooperative human activity involving utterances and forms of understanding (sayings), modes of action (doings), and ways in which people relate to one another and the world (relatings) that 'hang together' in characteristic ways in a distinctive 'project' (adapted from Kemmis \& Brennan Kemmis, 2014, April). Figure 1.1 shows this relationship. The project of a practice encompasses (a) the intention (aim) that motivates the practice, (b) the actions (interconnected sayings, doings, and relatings) undertaken in the conduct of the practice, and (c) the ends the actor aims to achieve through the practice (although it might turn out that these ends are not attained) (Rönnerman \& Kemmis, in press). For instance, when a teacher is engaged in the practice of teaching, one of the projects is very likely the support of student learning. 


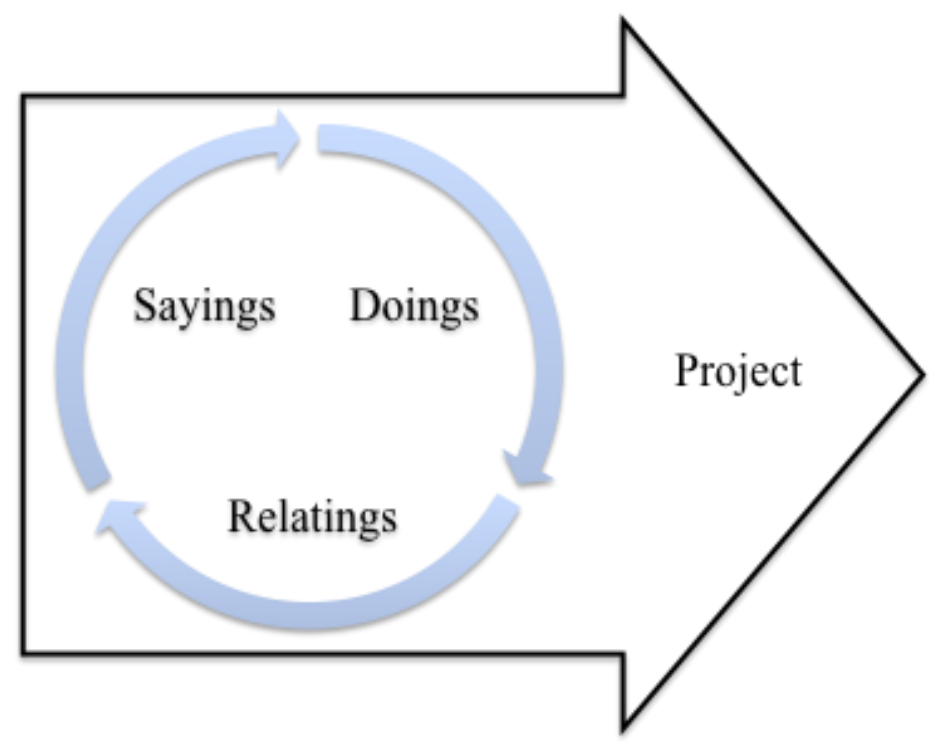

Figure 1.1. Practices are composed of sayings, doings, and relatings that hang together in projects. From Kemmis, Wilkinson et al. (2014, p. 33). Copyright 2014 by Springer Science+Business Media Singapore. Reprinted with permission from Springer.

The notion that sayings, doings, and relatings 'hang together' in a practice is important since sayings, doings, and relatings can occur independently of practices (Kemmis, Wilkinson et al., 2014, p. 26). In practices, particular kinds of relevant sayings, doings, and relatings are harnessed together in some kind of coherent way in the pursuit of the project of the practice (Kemmis, Wilkinson et al., 2014, p. 26). This is not necessarily without tension or contradiction. How they hang together is what gives particular kinds of practices their distinctiveness. Moreover, that the sayings, doings and relatings that comprise practices happen together means that practices cannot be reduced to any one of these actions on its own. To say these things "happen together" in the abstract is not very interesting; to those developing the theory of practice architectures, the interesting question is how some particular sets of sayings (language) come to hang together with a particular set of doings (in activity, or work), and a particular set of relatings (e.g., particular kinds of power relationships, or relationships of inclusion or exclusion). Thus, for example, an analyst of practices might explore how a particular activity like 'streaming' classes (grouping students into different classes on the basis of their ability or measured IQ) is justified by the particular sayings (e.g., using discourses of ability or intelligence), and the resulting social consequences for the students involved (e.g., social distinctions and exclusion between groups).

The theory of practice architectures holds that practices are social phenomena, and as such, are located in circumstances and conditions that occur in particular locations in physical space-time, and in history. Adopting Schatzki's $(2002 ; 2003 ; 2005 ; 2006 ; 2012)$ notion of 'site ontology', the theory of practice architectures suggests that practices are always situated (i.e., they happen) within a site or sites Schatzki (2002). The site of a practice is "that realm or set of phenomena (if any) of which it is intrinsically a part" (Schatzki, 2003, p. 176).

Practices, from a site ontological perspective, can be located in multiple sites at one time, and one practice can be the site of another practice (Schatzki, 2002). For example, teaching practice can be the site of assessment practice.

Being social and situated, practices are not just shaped by the experience, intentions, dispositions, habitus, and actions of individuals (Kemmis et al., 2012; Kemmis \& Grootenboer, 2008; Kemmis, Wilkinson et al., 2014). They are also shaped and prefigured intersubjectively by arrangements that exist in, or are brought to, particular sites of practice. 
In other words, practices are shaped and prefigured by arrangements "that exist beyond each person as an individual agent or actor" (Kemmis \& Grootenboer, 2008, p. 37). This is to say that a practice extends beyond what the individual enacting a practice brings to a site as a person (e.g., beliefs, physical attributes, and abilities); it also encompasses arrangements found in or brought to the site, arrangements with which the individual interacts, and without which the practice could not be realised ${ }^{5}$. Like the body of the person enacting the practice (practices are always embodied; Green \& Hopwood, 2015), these arrangements thus form a crucial part of the ontological ground that makes a practice possible.

The theory of practice architectures identifies three different kinds of arrangements that exist simultaneously in a site of practice ${ }^{6}$. These are cultural-discursive arrangements, material-economic arrangements, and social-political arrangements.

Cultural-discursive arrangements are the resources (in the broad sense of the word) that prefigure and make possible particular sayings in a practice, for example, languages and discourses used in and about a practice (Kemmis, Wilkinson et al., 2014, p. 32). They can constrain and/or enable what it is relevant and appropriate to say (and think) in performing, describing, interpreting, or justifying the practice (p. 32). In the case of teaching practices in a secondary classroom, for instance, cultural-discursive arrangements might include specialist discourses associated with particular disciplines (e.g., Mathematics, History), the language shared by the teachers and students (e.g., English, Finnish), or tacit codes about the level of formality appropriate for classroom conversation.

Material-economic arrangements are resources (e.g., aspects of the physical environment, financial resources and funding arrangements, human and non-human entities, schedules, division of labour arrangements), that make possible, or shape the doings of a practice by affecting what, when, how, and by whom something can be done. Again taking secondary school teaching practice as an example, material-economic arrangements shaping a teacher's classroom doings might include the classroom furniture and layout, audio-visual equipment, the timetable, access to support staff, student-teacher ratios, and teachers' employment contracts.

Social-political arrangements are the arrangements or resources (e.g., organisational rules; social solidarities; hierarchies; community, familial, and organisational relationships) that shape how people relate in a practice to other people and to non-human objects; they enable and constrain the relatings of a practice. Secondary teachers' ways of relating to students in their practice, for example, might be shaped by such arrangements as their position within the school staffing structure, their familiarity with the students, and/or codes of teacher conduct as specified by their school or employer.

Practices are thus always enmeshed ${ }^{7}$ with the cultural-discursive, material-economic, and social-political arrangements that occur in (or are brought to) a particular site. One might

\footnotetext{
${ }^{5}$ Referred to in Kemmis and Grootenboer (2008) as "extra-individual conditions" (p. 37) to distinguish these arrangements from conditions brought to a practice by the person doing the practice.

${ }^{6}$ This is a point of divergence between the theory of practice architectures and the work of Schatzki (2002). Rather than specifying three different kinds of arrangements that prefigure practice, Schatzki (2005) referred to such arrangements using a more general term: material arrangements. Following Wittgenstein (1957) Schatzki $(1996,2002)$ refers frequently to the 'sayings' and 'doings' that compose practices; the theory of practice architectures makes the 'relatings' of a practice explicit and prominent (rather than leaving them implied), because, as we discuss later, they point towards the dimension of solidarity and power that also permeates practices.

${ }^{7}$ Schatzki (2012) described the relationship between practices and material arrangements in terms of bundling. He depicted sites as "bundles" of practices and "material arrangements" (2012, p. 16). He used the word 'bundle' to reflect the inseparability of practices (e.g., teaching practice) and material arrangements (e.g., classrooms arrangements) within a site: "practices affect, use, give meaning to, and are inseparable from arrangements while ... arrangements channel, prefigure, facilitate, and are essential to practices" (2012, p. 16). Kemmis and colleagues, in contrast, use the term enmeshment in preference to 'bundling' when describing the
} 
say that practices are thus 'anchored' in these arrangements in a site, but the metaphor of 'anchoring' may suggest too stable and secure a relationship between a practice and the arrangements in a site ${ }^{8}$. To say that practices are 'enmeshed' with arrangements in a site recognises the fluidity and volatility with which practices engage with the particularities of arrangements in sites, and also recognises the variation, improvisation and innovation with which practices are enacted - variation, improvisation, and innovation which are observable in the enactment of practices in everyday life.

Speaking of sayings, doings, and relatings in relation (respectively) to the culturaldiscursive, material-economic, and social-political arrangements present in or brought to sites is not an arbitrary choice. On the contrary, the theory of practice architectures posits the social world as composed in three dimensions, specifically, "three dimensions of intersubjectivity" (Kemmis, Wilkinson et al., 2014, p. 23). Cultural-discursive arrangements are realised in semantic space, where people encounter each other intersubjectively "in the medium of language" (Kemmis, Wilkinson et al., 2014, p. 32). Material-economic arrangements are realised in physical space-time, where people encounter each other intersubjectively, as bodies, "in the medium of activity and work" (Kemmis, Wilkinson et al., 2014, p. 32). Social-political arrangements are realised in social space, where people encounter each other intersubjectively "in the medium of power and solidarity" (Kemmis. Wilkinson et al., 2014, p. 32). However, as noted in Kemmis, Wilkinson et al. (2014),

...in these three dimensions, cultural-discursive, material-economic and socialpolitical arrangements do not occur separately from one another; they are always bundled together in practice and in places. Bundled together, they give social life and our consciousness of it - its apparent solidity, its palpability, its reality and its actuality. (p. 5)

Figure 1.2 represents these three dimensions and their relationship to practices.

relationship between practices and arrangements, and reserve their use of the word 'bundle' and its variants for describing how sayings, doings, and relatings 'hang together', or how arrangements 'hang together'.

${ }^{8}$ Swidler (2001), for example, uses the notion of cultural practices being anchored and anchoring. See also Schatzki, 2012. 


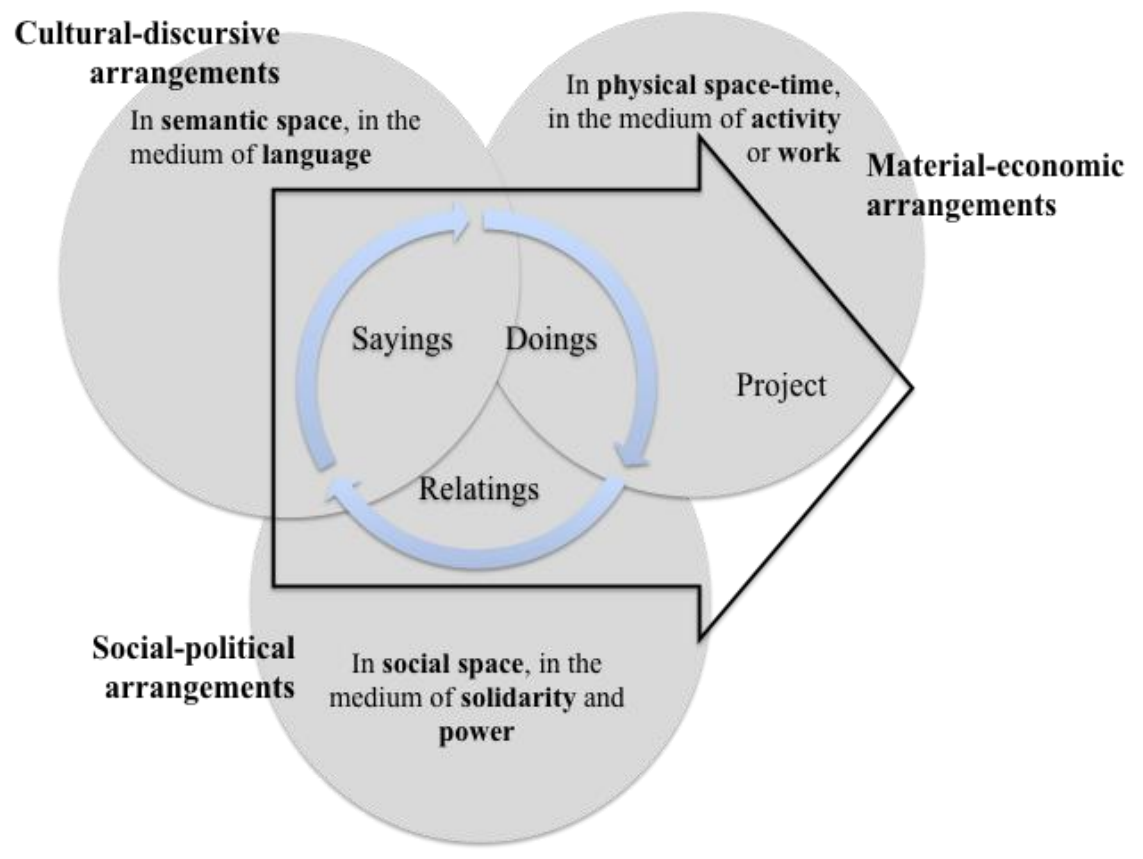

Figure 1.2. The media and spaces in which sayings, doings, and relatings exist. From Kemmis, Wilkinson et al. (2014, p. 34). Copyright 2014 by Springer Science+Business Media Singapore. Reprinted with permission from Springer.

The cultural-discursive, material-economic, and social-political arrangements that together shape or prefigure a particular practice are referred to as the practice architectures (Kemmis \& Grootenboer, 2008, p. 57) of that practice. Every practice has its own sitespecific practice architectures. These are the pre-conditions that make practice possible and hold it in place, prefiguring (Schatzki, 2002, p. 44) the unfolding of the practice. In other words, they are mediating conditions necessary but not sufficient for the enactment of the practice.

While practices are mediated by practice architectures, practice architectures are also mediated by practices. The following explanation of how practices shape the practice architectures for other practices highlights the complex, mutually-constitutive relationship between practices and practice architectures:

[Practices leave] behind in the setting particular kinds of discursive, physical and social traces or residues of what happened through the unfolding of the practice.

These traces or residues are left not only in participants' memories and interactional capacities but also in the practice itself as a site for sociality. Some of these residues become part of the practice architectures of the setting and are newly encountered by others who subsequently inhabit it - for example, when tomorrow's class discovers where the chairs were left in the classroom by today's students, or when new contributors to a debate in the research literature of a field find that the field has 'moved on' from the debates of earlier years. (Kemmis, Wilkinson et al., 2014, p. 29)

Rather than being fixed or stable, practice architectures evolve in response to various kinds of natural and social forces, and through human intervention (Kemmis, Wilkinson et al., 2014, pp. 4-5), including through practitioners' ongoing individual and collective practice. Kemmis (2009) argued that some practice architectures

have the weight of living and consciously remembered traditions of thought and action justifying them; some stay the same over time merely by habit; some are kept 
in their course by coercion or ideology; some are kept in place by rules and sanctions, by regulation and compliance mechanisms. (p. 34)

So, while the practice architectures that enable and constrain a particular practice are often already at hand in a site, new practice architectures can also be brought to, created in, and/or reconstituted in a site, prefiguring the practice in new, adapted, innovatory, or otherwise transformed ways. Such a notion has implications for those wishing to change practices since it signals the role and importance of human agency in the transformation of practice conditions.

As suggested by Kemmis's (2009) words just quoted, practice architectures can also be understood in terms of practice traditions. Practice traditions "encapsulate the history of the happenings of the practice, allow it to be reproduced, and act as a kind of collective 'memory' of the practice" (Kemmis, Wilkinson et al., 2014, p. 27). They carry the imprints of prior sayings, doings, and ways of relating enacted in a practice. In this way, the practice traditions of a practice form part of the practice architectures for that practice (and perhaps other practices). A 'schooling' practice tradition that has been reproduced over centuries is the delivery of instructions in a classroom from the 'front' of the room. The residues of this age-old practice are still visible, for example, in the way many modern classrooms are arranged with chairs and desks facing a wall furnished with a whiteboard or screen and 'teacher's desk' signifying the classroom 'front'. Conversely, the practice architectures of a practice are frequently embedded in practice traditions (as happens in the case of the enduring, established practices of a profession). The practice tradition of 'schooling' itself, at least from a western-European perspective, is characterised by recognisable culturaldiscursive, material-economic, and social-political arrangements. The very idea of a 'classroom' as a designated place of teaching and learning has a firm place in this tradition, it would seem.

The way in which practice traditions, practices, practitioners, practice architectures, and sites of practices interrelate in the three dimensions of intersubjectivity is represented diagrammatically in Figure 1.3. The diagram highlights the dialectal relationship between practitioners and practice architectures through the use of the infinity symbol $(\infty)$. The symbol is intended to be read as a kind of flow, holding together bundled-together sayings, doings, and relatings, on the one side, with, on the other, the cultural-discursive, materialeconomic, and social-political arrangements that make them possible. To Kemmis, the infinity symbol also has a deeper meaning, evoking this famous sentence from Marx's (1845) third thesis on Feuerbach:

The materialist doctrine that ... [people] are products of circumstances and upbringing, and that, therefore, changed ... [people] are products of changed circumstances and changed upbringing, forgets that it is ... [people] who change circumstances and that the educator must himself [or herself] be educated.

In Kemmis's view, the left loop of the infinity symbol in the diagram (Figure 1.3) embraces the individual who enacts a practice (the person who is the product of circumstances and upbringing, who can change circumstances, and who must be educated), while the right loop embraces the site in which the arrangements together form the practice architectures for the practice (which are the historical circumstances that both form people and can be changed by people). In a true dialectical relationship, like the relationship of the chicken and the egg, each proceeds from the other. 


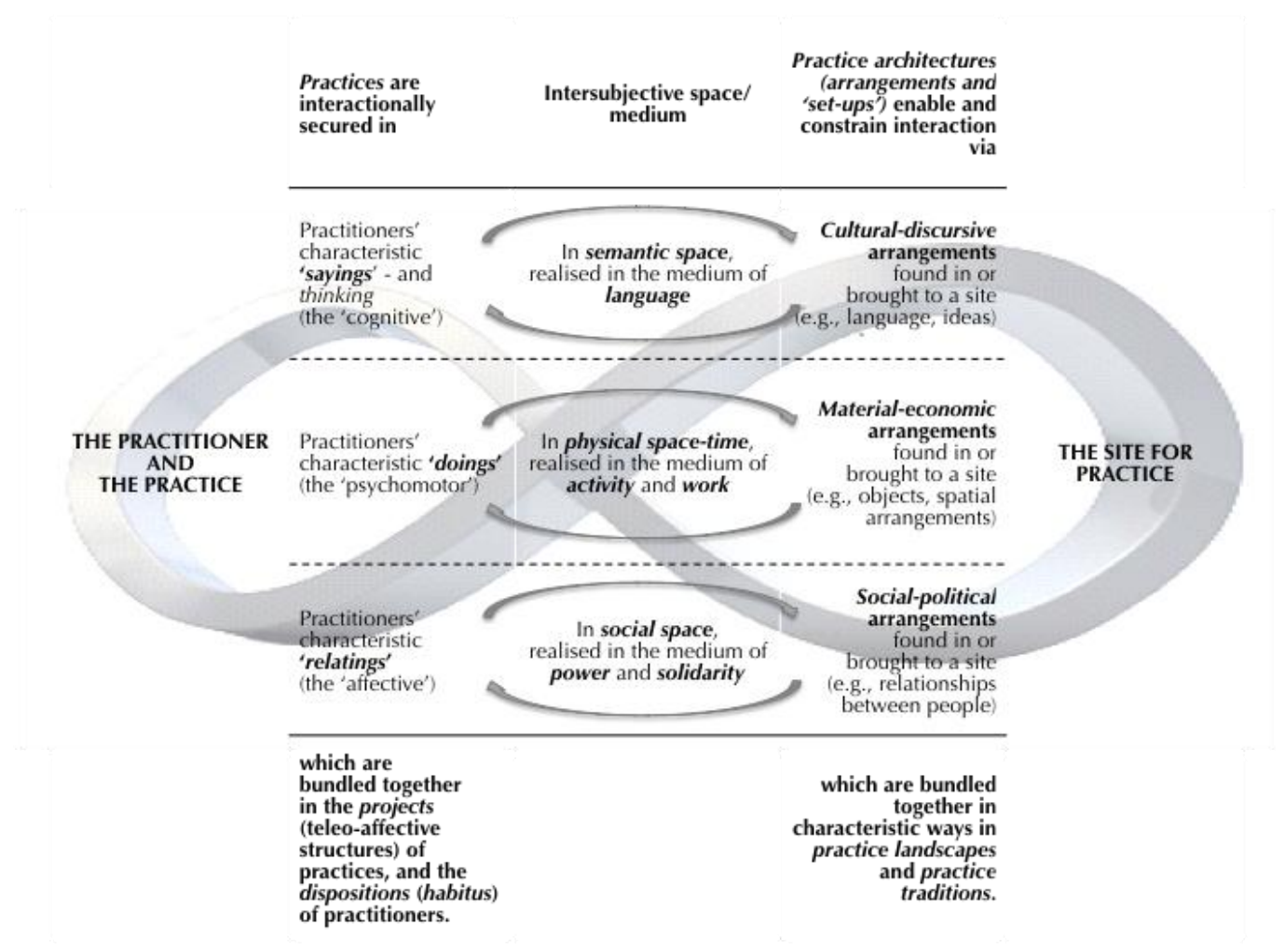

Figure 1.3. The theory of practice architectures. From Kemmis, Wilkinson et al. (2014, p. 38).

Copyright 2014 by Springer Science+Business Media Singapore. Reprinted with permission from Springer. Note that the word 'practitioner' on the left hand side of the diagram denotes participants in a practice in a general sense rather than participants in a professional practice specifically.

Practitioner, in this more general sense does not exclude babies, for example, if we happen to be talking about the practices of babies (as Salamon does in Chapter 5 of this book).

Importantly, the theory of practice architectures takes into account the notion that practice may be enacted as praxis. In the theory of practice architectures, this contested construct is represented as a special form of practice. The term is used in both a neoAristotelian sense to denote "action that is morally-committed, and oriented and informed by traditions in a field" (Kemmis \& Smith, 2008, p. 4) and in a post Hegelian and post Marxian sense to denote "history making action" (Kemmis, 2010a, p. 9). Praxis, which can be enacted by people individually or collectively involves acting in ways that are morally, ethically, and politically responsible, and acting with awareness that when we act, we are acting in history, changing the world around us, even if only in small ways. Reference to both practice and praxis in the theory of practice architectures acknowledges that practices have a moral, not just a technical dimension. Practices always have consequences; the unfolding or anticipation of these consequences inform the conduct of the practice. Because moral consequences of a practice are site- and situation-specific, many practice situations demand moral-ethical judgement and creative problem solving, rendering reliance on prescribed procedures or rulefollowing action inappropriate. The emphasis on practice as praxis is elaborated in the final part of this chapter.

That practices have cultural, material, moral, social, and political consequences is highly relevant to the question of the relationships that exist between practices, since the effects and consequences of one practice can shape other practices. This brings us to the theory of the ecologies of practices (Kemmis et al., 2012), an extension of the theory of practice architectures. The notion of ecologies of practices is an account - based on 
ecological concepts drawn from Capra $(1997,2004,2005)$ - of how practices can come to relate to each other in social sites. The theory holds that practices do not exist in isolation from other practices. Rather, they are "like living entities" that can be ecologically related to each other; they sometimes "coexist" in complex ecologies or webs of practices that are "like living systems" (Kemmis, Wilkinson et al., 2014, p. 41) ${ }^{9}$. It is an empirical question whether or not one practice is in a relationship of interdependence with another practice, not an abstract idea. In the same way that living entities can become interdependent, so too can practices, for example, when the product or outcomes of one practice "are taken up in other practices" (Kemmis et al., 2012, p. 34). Furthermore, practices can adapt and evolve in relation to, and be constrained and enabled by, each other. This means that practices can become practice architectures for other practices; see Kemmis Wilkinson et al. (2014) for a substantive, empirically-based account of interdependent relationships between five educational practices that comprise what the authors refer to as the 'education complex': learning practices, teaching practices, professional learning practices, leading practices, and researching, where researching practices include "self-study on the part of teachers and administrators" (p. xi).

Practices, practice architectures, and practice traditions are not only said to exist in, and comprise, sites of practice and ecologies of practices. They are also described as being enmeshed with each other in particular ways in practice landscapes (Kemmis, Wilkinson et al., 2014, p. 4, 34). Following Schatzki (2010), the notion of practice landscapes refers to practice settings, such as early childhood centres, hospitals, TAFE Institutes, or schools, where multiple kinds of different practices occur, and in which there may be multiple and overlapping sites of practice ${ }^{10}$. From an ecological perspective, a practice landscape can sometimes be described as a niche for a particular practice when that landscape has the necessary practice architectures (conditions of possibility) in place for the practice to exist or to be sustained (Kemmis \& Heikkinen, 2012; Kemmis, Wilkinson et al., 2014). These and other key terms in the theory are summarised in Table 1.1, presented at the end of this chapter.

So far in this chapter, we have provided a brief sketch of the theoretical landscape of practice theory, and an explanation of the theory of practice architectures itself. Next we bring the theory of practice architectures and practice theory together to provide a sense of what is distinctive about the theory of practice architectures as a practice theory, and what it contributes to ongoing conversations and projects concerned with practices, professional practice, and education.

\section{What is Distinctive and Significant about the Theory of Practice Architectures?}

Like any substantive theory, the theory of practice architectures ought to be viewed in relation to the theoretical landscape to which it belongs and responds. With this in mind, in this section of the chapter, we locate the theory of practice architectures within the theoretical landscape of practice theory and highlight what is distinctive and significant about it as a theory of practice. Note that contextualisation of the theory is taken a step further in Chapter 13, where Kemmis and Mahon trace the theory's development and key influences.

\section{The theory of practice architectures and practice theory}

There are some clear points of convergence between the theory of practice architectures and other practice theories, not least an emphasis on practices as a starting point

\footnotetext{
${ }^{9}$ For a more detailed elaboration of the theory of ecologies of practices see Kemmis et al. (2012).

${ }^{10}$ Note that a practice landscape is also a site of practice. It is a site that has multiple sites of practice nested within it.
} 
for examining social reality, and theoretical borrowings from Aristotle and Marx, and work such as MacIntyre (1981), Schatzki (2002, 2010, 2012) and Giddens (1984) (see Chapter 13 for more details and other influences). Like other practice theories, the theory of practice architectures rejects dualisms and asserts that practices are situated, embodied, and indeterminate. They are prefigured by arrangements (conceptualised as practice architectures). What especially locates the theory of practice architectures in relation to other practice theories, however, is that it (a) politicises practice; (b) humanises practice; (c) theorises relationships between practices; (d) adopts an ontological perspective (although it also addresses some epistemological questions); and (e) offers insights pertaining to education. In the following paragraphs we unpack this statement.

That the theory politicises practice ${ }^{11}$ makes it similar in some respects to the work of Bourdieu, Giddens, and Foucault, who are known particularly for their attention to power and the political. What differentiates the theory of practice architectures from their work and that of others who attend to power is the four distinctive ways in which it foregrounds the political dimensions of practice.

The first of these is the theorising of the three overlapping dimensions of intersubjectivity: cultural-discursive, material-economic, and social-political. By identifying these three intersubjective dimensions, the theory highlights the complexity of sites of practice and the complexity of relationships between practices and sites, building on Schatzki's work in some respects. It also pays equal and due attention to the role of language, work, and power in the constitution of practices, showing how all three work together to make particular kinds of practice possible or impossible. In doing so, it has re-injected the practice debate with the critical insights of Habermas $(1972,1974)$ and Marx $(1845,1852)$.

The second way the theory politicises practice is by making explicit the relatings of practices. Schatzki (2002) described practices as nexuses of sayings and doings. While relatings are implicit in sayings and doings, the addition of relatings (i.e., a practice as a nexus of sayings, doings, and relatings) accounts specifically for those aspects of practices connected to palpable relationships between people (Kemmis \& Grootenboer, 2008, p. 38) and between people and the material world. This foregrounds such relational aspects of practice as "solidarity", "power" (Kemmis, Wilkinson et al., 2014, p. 30), inclusion/exclusion (Kemmis, 2009), trust, and positionality, all of which can have moral-political significance.

The third is through the deliberate attention to how practices are constrained and enabled and the critical choice to use the language of 'constraining and enabling' in addition to prefiguring. (This contrasts with Schatzki's (2012) preference for using 'prefiguring' rather than 'constraining and enabling'.) The words constrain ${ }^{12}$, and enable sensitise us, as agentic beings, to the consequences of practices, and what we are doing when we create and sustain constraining and enabling practice architectures.

The fourth is that it accounts for praxis and, moreover, provides a fully theorised account of praxis (see Kemmis \& Smith, 2008; Kemmis \& Grootenboer, 2008). Few practice theories do this. The inclusion and theorisation of praxis reflects an ethical commitment on the part of the authors to contributing to a more sustainable, just, and healthy society. This locates the theory of practice architectures in the practice theory landscape as a practice theory underpinned by an explicit transformative agenda.

The theory of practice architectures is also located within the field of practice theory as a theory that attempts to humanise practices and that rejects an objectivist approach to practice. There is a danger that, in focussing on routines of practice, and on sociality as

${ }^{11}$ This is not to suggest that practice is not already political.

${ }^{12}$ The word 'constrain' is not necessarily associated with negative outcomes. What constrains a practice may be preventing paths from being open because it is channelling action (via particular fences and boundaries) towards something else that has positive consequences. 
something 'out there', theorists of practice might lose sight of the actual people whose sayings (and thinkings), doings, and relatings compose a practice. The theory of practice architectures has addressed this concern by attending to aspects of practice such as human agency and projects (incorporating the intentions of actors), and by acknowledging the role of dispositions in shaping practice. See the reference to dispositions in Figure 1.3 above, and the discussion of dispositions in Kemmis and Smith (2008). People matter in accounts of practice, since practitioners cannot be separated from their practice (Kemmis \& Smith, $2008)^{13}$. Bourdieu (1990) acknowledged this with his theorisation of habitus. The theory of practice architectures makes allowance for the role of people's life narratives, taking where necessary the term 'site' in its broadest sense to include a human life as a site of practice in which people's dispositions, intentions, and sense of agency as well as their practices are shaped intersubjectively, as people encounter each other in shared, and often contested, semantic spaces, physical space-time, and social space.

Attention to praxis has a similar humanising effect. The inclusion of praxis in the theory was part of a deliberate decision not to "take the actor out of the act" or "the person out of the unfolding events" since "praxis is the action of people who act in the knowledge that their actions will have good and ill consequences for which they have sole or shared responsibility, and who, in that knowledge, want to act for the good" (Kemmis \& Smith, 2008, p. 8).

Another aspect of the theory that distinguishes it from other practice theories is its focus on interdependencies between practices through the notion of ecologies of practices. It is not unusual for practice theorists to write about practices in ecological terms. Gherardi (2009) for example noted "theories of practice assume an ecological model in which agency is distributed between humans and non-humans and in which the relationality between the social world and materiality can be subjected to inquiry" (p. 115) and "theories of practice view actions as ... being performed through a network of connections-in-action" (Gherardi, 2009 , p. 115). However, Kemmis and colleagues have gone beyond metaphorical reference to ecological relationships to a fully theorised account, built around ecological principles, of how practices relate to each other (see Kemmis et al., 2012; Kemmis \& Heikkinen, 2012; Kemmis, Wilkinson et al., 2014).

As we have intimated, the theory of practice architectures, like many other practice theories, offers an ontological perspective on practice. Its main concern is with what practices are; how practices happen; how they are shaped, constrained, and enabled; and what practices do. These are ontological questions. However, more recent iterations of the theory address epistemological concerns (e.g., how we learn in practice). The theory now incorporates the notion - following Wittgenstein's (1957) ideas about people being initiated into language games - of learning as a process of being 'stirred into' practices (Kemmis et al., 2012; see also Kemmis, Wilkinson et al., 2014), or 'stirred into' the sayings, doings, ways of relating, and the projects characteristic of practices, whilst in practice. This is based on an understanding of knowledge and meaning as located in intersubjective spaces, that is, in the " "happening' ... of language games, activities, ways of relating, and practices in which particular words are used, particular things are done, and particular relationships exist in the interactions between the people and things involved" (Kemmis, Wilkinson et al., 2014, p. 51). So, in theorising these aspects of practice, there are some comparisons that can be made with other accounts of how people come to know in a practice (cf. Lave \& Wenger, 1991;

13 This is a point of distinction between the theory of practice architectures and other theories that ascribe agency to material artefacts (e.g., actor network theory) as mentioned in the first part of the chapter. "Matter matters" (Fenwick, 2010, p. 106) in the theory of practice architectures, but not to the point of assuming agentic status equivalent to that of humans in practice. How and that matter (i.e., the material) matters, is still seen as a matter of human sense-making. 
Gherardi, 2006; Nicolini, 2011). The theory nevertheless remains very much ontological in its orientation.

A last distinctive feature of the theory of practice architectures is that it also provides a basis for a contemporary theory of education appropriate for the modern world (Kemmis, Wilkinson et al., 2014) and a lens for exploring learning. It does so, firstly, through the conceptualisation of education as a practice, and, as just discussed, learning as a process of being initiated or stirred into practices (see Kemmis, Wilkinson et al., 2014). Although the notion of 'stirring in' is not a new concept, the theory of practice architectures gives it substance and 'fills out' our understanding of learning. This goes some way toward helping us understand what education is. Learning and the concept of being stirred into practice are as relevant to professional practices such as nursing and plumbing as they are to practices related to schooling. Secondly, the articulation of the 'education complex' (Kemmis, Wilkinson et al., 2014) helps to shed light on how learning practices shape and are shaped by other educational practices in school settings. Thirdly, the authors of the theory have made explicit links between the theory of practice architectures and the project of education - as contested as that project is - and whether and how practice architectures shaping education today are making possible, or hindering, the achievement of what Kemmis, Wilkinson et al. (2014) describe as the "double purpose of Education: to help people to live well in a world worth living in" (p. 21). Chapter 13 provides a discussion of, and a diagram showing, these links.

The distinctive aspects of the theory just described, and the theory's response to existing practice theories, provide a unique contribution to the contested space of the practice theory landscape. The theory is significant in other ways too, as we discuss next.

\section{The theory of $\mathrm{PA}^{14}$ as a theoretical, analytical, and transformational resource}

We believe that the theory of practice architectures furnishes many affordances, some of which will be evident in the case chapters that follow this chapter. Here we identify three main ways in which we think it is useful, having all drawn on the theory in our own research. As we mentioned in the introduction to this chapter, it is at once a theoretical resource, an analytical (or methodological) resource, and a transformational resource for those with interests in education and professional practice.

The theory is a valuable theoretical resource in that it provides an accessible and concise language for describing and interpreting the social world (in contrast to some of the more diffuse theories of practice already at our disposal). Yet the theory of practice architectures is comprehensive in its conciseness. It enables us to say how practices and practice architectures relate, and how they are interdependent, in a way that captures the complexity of relationships between practices and the arrangements that make them possible and hold them in place. This is important for our own sayings and thinkings/understandings as researchers, theorists, practitioners, and/or educators about the social spaces we inhabit. See Table 1.1 below for an explanation of key terms and concepts.

Related to this, the theory is also a useful analytical resource. As an analytical lens, it allows us to identify actual empirical connections between practices and arrangements. The theory of practice architectures steers analysis towards what actually happens in a site, and the identification of the local arrangements that make practices of a particular kind possible within that site, or that shape local (site-based) variations of a practice. The theory does not offer a particular methodology, nor a set of strategies for doing the empirical work, but it does prompt the asking of new questions (that might be answered in a multitude of ways as the case chapters in this book attest) or thinking about old questions in new ways, for example,

\footnotetext{
${ }^{14}$ Practice architectures.
} 
What is it we are doing (i.e., what are we saying/thinking, physically doing, and how are we relating?) when we enact a particular practice?

What are the consequences of our current sayings, doings, and ways of relating?

What practice traditions, practices, and practice architectures are holding the current practices in place or making them possible, and how?

What cultural-discursive, material-economic, social-political arrangements enable and constrain the enactment of practice as praxis?

What is the role of human agency and power in constructing the practice architectures necessary for, or inhibiters to, the sustainability of particular kinds of practice?

The theory of practice architectures focuses on aspects of social situations that might be indeterminate and boundless, but that are nevertheless tangible and thus empirically manageable. Furthermore, the authors of the theory have provided detailed accounts of how they have put the theory to work in their own research analysis (see, for example, Kemmis, Wilkinson et al., 2014, especially the Appendix, pp. 223-272). This helps to address some of the issues highlighted by Nicolini (see 2013, pp. 180-81) about Schatzki's work in terms of being too theoretical and leaving gaps regarding how empirical work informed by Schatzki's ideas might be conducted.

Importantly, the theory provides a critical lens for critiquing aspects of the social world that create and contribute to unsustainability, unreasonableness, and injustice. It is easy to brush aside notions of power in examining practice. The theory of practice architectures, by drawing attention to 'relatings' on the one hand, and social-political arrangements on the other, keeps questions about power at the centre of inquiry and thinking about practice. It acknowledges that sites of practice are sites of contestation, contradiction, tension, and struggle, and raises questions about what avenues for acting (saying, doing, and relating) are opened up, and closed down, by particular power dynamics at play. This includes in the practice of researching education and professional practice; see, for example, Pennanen, Bristol, Wilkinson, and Heikkinen's Chapter 12 in this volume.

In this respect, the theory is also a transformational resource. The theory of practice architectures can provide pathways for transforming education and professional practice (and research about these things) through site-based development. On February $19^{\text {th }}, 1941$, Winston Churchill, appealing for support to US President Franklin D Roosevelt, famously said "give us the tools and we'll finish the job". If we put the theory of practice architectures to work analytically in our own sites of practice, it can help us to identify what tools we need to finish the job, or, more accurately, to get on with the never-ending job of transforming education, and transforming professional practice more generally. It can be used as a framework for making practical judgements about what ought to be done in the situations at hand, that is, in response to site-based conditions and circumstances.

As this book shows, the theory of practice architectures is already being put to work as a theoretical, analytical, and/or transformational resource in a variety of professional and educational settings. Some of this work takes the form of critical hermeneutics that explores why and how situations have become untoward (in the sense that they are unreasonable, unproductive or unsustainable, or the cause of suffering or injustice, or a combination of these). The book also shows examples of other work that takes the form of collaborative reflexive inquiry in which participants use the theory as a theoretical and analytical resource to understand their current practices and the practice architectures that hold their current practices in place, and, in the light of these insights and analyses, use the theory to deliberate practically about how to transform both their current practices and the situations in which they find themselves, in order to avoid or overcome any untoward consequences. 


\section{Organisation of the Book}

In this chapter, we have laid a foundation for the case chapters in the book by introducing and locating the theory of practice architectures, the theory that the authors of the case chapters have variously put to work in their respective inquiries about education and/or professional practice. We have done so, first, by providing a brief sketch of the field of practice theory, second, by explicating some of the central ideas of the theory, and third, by locating the theory of practice architectures in relation to other practice theory and providing a snapshot of the distinctive contribution the theory is already making to practice inquiry.

From here the book takes us on several journeys of the theory in use, each of which is significant and distinctive in its own way. In Chapter 2, authors Christine Edwards-Groves and Peter Grootenboer closely examine practices in two Australian primary school classrooms, using the theory of practice architectures to productively zoom in on the practices that teachers and students co-produce through their language, actions, and interactions with each other as lessons unfold. Ela Sjølie takes us to the other end of the educational spectrum in Chapter 3 to discuss a Norwegian study of students' learning practices in university-based teacher education. Sjolie uses the theory of practice architectures to disrupt common (mis)understandings of theory-practice relations in initial teacher education, and to offer important insights into the challenges pre-service teachers face when they engage with educational theory in their initial teacher education studies.

Staying with the theme of university-based professional education, Chapter 4 by Nick Hopwood draws on an observational study of simulation classes in an undergraduate nursing degree. Hopwood creatively puts the theory of practice architectures in conversation with Baudrillard's concepts of hyper-reality and simulacra to make a compelling case for rethinking simulation pedagogy in health professional education. In Chapter 5, we are prompted by Andi Salamon to rethink the agentic capacity of babies. Salamon reports on a study of practices in a particular early childhood setting, showing how early childhood educators' practices are shaped by their conceptions of babies' capabilities. The implications of certain conceptions for early childhood education pedagogy and babies' learning are explored through narratives of babies' interactions with educators and other babies. An interesting reinterpretation of 'sayings' in light of babies' pre-verbal capacities forms a key part of Salamon's argument.

Chapter 6 turns our attention to mentoring practices and Vocational Education and Training (VET) teacher learning. In the chapter, author Susanne Francisco introduces the idea of a trellis of practices that support learning, building on ideas articulated in the theory of ecologies of practices. The notion of a trellis emerges out of a discussion of the ecological relationships between mentoring and other practices that support learning in a longitudinal study involving novice VET teachers working in Australian Technical and Further Education (TAFE) colleges. In Chapter 7, Annette Green, Roslin Brennan Kemmis, Sarojni Choy, and Ingrid Henning Loeb explore the practice architectures supporting the practices of novice VET in Schools (VETiS) teachers. The chapter shows how these teachers' practices differ from other high school teachers' practices because of the VETiS teachers' histories of working in other industries, and their established ways of working with young people in those settings (as trainees and apprentices).

Chapters 8 and 9 zoom in on professional practice in schools. In Chapter 8, Lill Langelotz presents new insights into mentoring practices (also a focus of Chapter 6) in the context of continuing professional development of school teachers. The chapter fruitfully draws on both the theory of practice architectures and Foucault's notion of power to examine what enabled and constrained teachers' peer group mentoring practices in a particular school in Sweden, and what this meant for teachers' professional learning. In Chapter 9, Lena Tyrén takes up the themes of teacher professional learning and power. She presents a narrative of 
how Swedish economic reform affected practices within a primary school during its implementation of a school development program (framed as action research). The chapter illustrates what can happen when national policy and local aspirations for practice in schools collide.

The next two chapters also shed light on endeavours to realise particular aspirations. In Chapter 9, Jane Wilkinson examines attempts by a school executive to enact leadership as a socially just practice and praxis. The story of how school leaders challenged particular arrangements affecting the learning and experiences of students for whom English is an additional language or dialect [EALD] (including students of refugee background) provides powerful insights into the interconnectedness between leading and other practices within schools (e.g., enacting policy, professional learning, researching and reflecting, and students' learning practices), and the implications of this for transforming school culture. In Chapter 11, Kathleen Mahon and Letitia Galloway discuss the impact of structural change (a departmental merger) within a university faculty on academics' endeavours to enact teaching practice as critical pedagogical praxis. The concerning but hopeful narrative shows how possibilities for critical pedagogical praxis can be negatively affected by mergers, but also ways in which academics can negotiate changing conditions and create enabling architectures amidst challenges.

Chapter 12, the final case chapter, takes us on a very different journey by turning the lens of practice architectures on researchers' practices. Matti Pennanen, Laurette Bristol, Jane Wilkinson, and Hannu Heikkinen provide a reflexive analysis of their collaborative research practices. They put the spotlight on the kinds of arrangements that enabled and constrained their sayings, doings, and relatings as researchers in an international research project, and in doing so, provide insights into what shapes collaborative research practices, and also some of the challenges researchers can face when using the theory of practice architectures.

The authors of Chapters 13 and 14 return readers' focus to the theory of practice architectures. In Chapter 13, Stephen Kemmis and Kathleen Mahon discuss the development of the theory, referring to some of the earlier theories that influenced its formation. Chapter 14, by Stephen Kemmis, Jane Wilkinson, and Christine Edwards-Groves, clarifies some of the key terms of the theory that have sometimes seemed ambiguous or confusing to people using it. Some of these ambiguities and confusions came to light in discussions among authors in the preparation of this volume. Chapters 13 and 14 serve as a reminder that the theory is both an historical product and a work in progress. Chapter 15, written by editors Susanne Francisco, Kathleen Mahon, and Stephen Kemmis, concludes the volume with a brief comment about the lens of practice architectures, as used in this book, commenting briefly on some of the significant narratives, themes, and insights that the chapters collectively contribute to our understanding of education and professional practice.

Together, the chapters tell an important story of possibility. They bring into view areas of education and professional practice that demand more focussed attention, and in some areas, a rethinking of commonly held views. We invite readers interested in educational and professional practice, and in the theoretical, practical and transformative possibilities opened up by the theory of practice architectures, to join the conversation this volume documents and extends. 
Table 1.1.

Key terms associated with the theory of practice architectures

\begin{tabular}{|c|c|c|}
\hline Key terms & $\begin{array}{l}\text { How used in the theory of practice } \\
\text { architectures }\end{array}$ & $\begin{array}{l}\text { Examples of chapters in which } \\
\text { these key terms are in focus or } \\
\text { problematised. }\end{array}$ \\
\hline $\begin{array}{l}\text { Cultural- } \\
\text { discursive } \\
\text { arrangements; } \\
\text { material- } \\
\text { economic } \\
\text { arrangements; } \\
\text { social-political } \\
\text { arrangements }\end{array}$ & $\begin{array}{l}\text { The three different kinds of arrangements that } \\
\text { constitute sites of practice, and that shape } \\
\text { practices. } \\
\text { Cultural-discursive arrangements prefigure } \\
\text { and make possible particular sayings in a } \\
\text { practice by constraining and/or enabling what } \\
\text { it is relevant and appropriate to say (and } \\
\text { think) in performing, describing, interpreting, } \\
\text { or justifying the practice. } \\
\text { Material-economic arrangements shape the } \\
\text { doings of a practice by affecting what, when, } \\
\text { how, and by whom something can be done. } \\
\text { Social-political arrangements shape how } \\
\text { people relate in a practice to other people and } \\
\text { to non-human objects. (Kemmis, Wilkinson et } \\
\text { al., 2014, p. 32). }\end{array}$ & $\begin{array}{l}\text { Sjølie (Chapter 3) } \\
\text { Langelotz (Chapter 8) } \\
\text { Green, Brennan Kemmis, Choy, \& } \\
\text { Henning Loeb (Chapter 7) } \\
\text { Tyrén (Chapter 9) } \\
\text { Wilkinson (Chapter 10) } \\
\text { Pennanen, Bristol, Wilkinson, \& } \\
\text { Heikkinen (Chapter 12) }\end{array}$ \\
\hline $\begin{array}{l}\text { Ecologies of } \\
\text { practices }\end{array}$ & $\begin{array}{l}\text { Empirically discovered relationships between } \\
\text { practices in a site. }\end{array}$ & $\begin{array}{l}\text { Francisco (Chapter 6) } \\
\text { Wilkinson (Chapter 10) }\end{array}$ \\
\hline $\begin{array}{l}\text { Education } \\
\text { complex }\end{array}$ & $\begin{array}{l}\text { The group of five practices "that have been } \\
\text { interconnected with one another since the } \\
\text { emergence of mass compulsory schooling in } \\
\text { the mid-nineteenth century in the West, } \\
\text { namely: (1) student learning, (2) teaching, (3) } \\
\text { professional learning, (4) leading, and (5) } \\
\text { researching." (Kemmis, Wilkinson et al., } \\
2014, \text { p. } 37)\end{array}$ & Wilkinson (Chapter 10) \\
\hline $\begin{array}{l}\text { Enmeshed (or } \\
\text { enmeshment) }\end{array}$ & $\begin{array}{l}\text { The term 'enmeshed' is used to describe the } \\
\text { relationship between practices and } \\
\text { arrangements, as in 'practices and } \\
\text { arrangements are enmeshed in a practice'. The } \\
\text { words 'entangled', 'entwined', and 'coupled' } \\
\text { are sometimes used instead of enmeshed. } \\
\text { The word 'enmeshed' is used in much the } \\
\text { same way that Schatzki uses the word } \\
\text { 'bundle'. In the theory of practice } \\
\text { architectures, the word 'bundle' is reserved } \\
\text { for the descriptions of how sayings, doings, } \\
\text { and relatings hang together in the project of a } \\
\text { practice: } \\
\text { 'In practice, sayings, doings, and relatings are } \\
\text { bundled together in a distinctive project'. }\end{array}$ & Langelotz (Chapter 8) \\
\hline $\begin{array}{l}\text { Extra-individual } \\
\text { conditions }\end{array}$ & $\begin{array}{l}\text { Conditions "that exist beyond each person as } \\
\text { an individual agent or actor" (Kemmis \& } \\
\text { Grootenboer, 2008, p. 37). } \\
\text { The expression "extra-individual" was used } \\
\text { by Kemmis in his earlier work (see Kemmis, } \\
\text { 2005, and references to "extra-individual } \\
\text { features of practice" - p. 393). It appears in } \\
\text { the original explication of the theory of } \\
\text { practice architectures (see Kemmis \& }\end{array}$ & \\
\hline
\end{tabular}




\begin{tabular}{|c|c|c|}
\hline & $\begin{array}{l}\text { Grootenboer, 2008, p. 37), but not in recent } \\
\text { accounts. }\end{array}$ & \\
\hline $\begin{array}{l}\text { Hanging together } \\
\text { (and bundling) }\end{array}$ & $\begin{array}{l}\text { Hanging together, borrowed from Schatzki } \\
\text { (1996), implies a connectedness and co- } \\
\text { existence between entities concerned. See } \\
\text { Schatzki (1996) on 'hanging together' and } \\
\text { Wittgenstein's interpretation of } \\
\text { Zusammenhang. - "state of held- } \\
\text { togetherness" (1975, as cited in Schatzki, } \\
\text { 1996, p. 14, 171). } \\
\text { See also 'enmeshment' above. }\end{array}$ & $\begin{array}{l}\text { Edwards-Groves \& Grootenboer } \\
\text { (Chapter 2) }\end{array}$ \\
\hline $\begin{array}{l}\text { Intersubjective } \\
\text { space }\end{array}$ & $\begin{array}{l}\text { The space that lies between people (Kemmis, } \\
\text { Wilkinson et al. 2014, p. 4). } \\
\text { According to the theory of practice } \\
\text { architectures, there are three kinds of } \\
\text { intersubjective space: semantic space, } \\
\text { physical space-time, and social space. }\end{array}$ & $\begin{array}{l}\text { Edwards-Groves \& Grootenboer } \\
\text { (Chapter 2) } \\
\text { Sjølie (Chapter 3) - semantic, social } \\
\text { space (dimensions) } \\
\text { Pennanen et al. (Chapter 12) }\end{array}$ \\
\hline Meta-practices & $\begin{array}{l}\text { The notion of meta-practices was used to } \\
\text { denote practices that shape other practices } \\
\text { (Kemmis \& Grootenboer, 2008, p. 39). Since } \\
\text { many, many practices shape other practices, } \\
\text { this expression has fallen by the wayside as } \\
\text { the theory has been refined. }\end{array}$ & \\
\hline Niche & $\begin{array}{l}\text { An ecological metaphor for the conditions of } \\
\text { possibility for a practice. The niche of a } \\
\text { practice is composed of the cultural- } \\
\text { discursive, material-economic and social- } \\
\text { political arrangements in a site that make this } \\
\text { particular practice possible. }\end{array}$ & Hopwood (Chapter 4) \\
\hline Practice & $\begin{array}{l}\text { A socially established cooperative human } \\
\text { activity involving utterances and forms of } \\
\text { understanding (sayings), modes of action } \\
\text { (doings), and ways in which people relate to } \\
\text { one another and the world (relatings) that } \\
\text { 'hang together' in characteristic ways in a } \\
\text { distinctive 'project' (adapted from Kemmis \& } \\
\text { Brennan Kemmis, 2014, April). }\end{array}$ & $\begin{array}{l}\text { Sjolie (Chapter } 3) \text { - its relationship to } \\
\text { theory } \\
\text { Salamon (Chapter 5) - infants lived } \\
\text { experiences as infant practices } \\
\text { Hopwood (Chapter 4) - simulation } \\
\text { practices as 'real' practices } \\
\text { Wilkinson (Chapter 10) practices as } \\
\text { contested }\end{array}$ \\
\hline $\begin{array}{l}\text { Practice } \\
\text { architectures }\end{array}$ & $\begin{array}{l}\text { The practice architectures of a practice are the } \\
\text { particular cultural-discursive arrangements, } \\
\text { economic-material arrangements, social- } \\
\text { political arrangements that together make } \\
\text { possible, and shape, that practice. }\end{array}$ & All \\
\hline $\begin{array}{l}\text { Practice } \\
\text { landscape }\end{array}$ & $\begin{array}{l}\text { Following Schatzki (2010), practice } \\
\text { landscapes refers to practice settings (e.g., } \\
\text { early childhood centres, hospitals, TAFE } \\
\text { Institutes, schools) where multiple kinds of } \\
\text { different practices occur, and in which there } \\
\text { may be multiple and overlapping sites of } \\
\text { practice. The term encompasses the people } \\
\text { who are emplaced in the setting, the practices } \\
\text { that are enacted there, the practice } \\
\text { architectures that give the setting its character, } \\
\text { and the practice traditions that have been } \\
\text { established in the setting over time. It } \\
\text { encompasses the relationships between } \\
\text { practices, practice architectures, and practice } \\
\text { traditions within, and constituting, the setting. }\end{array}$ & $\begin{array}{l}\text { Pennanen et al. (Chapter 12) } \\
\text { Mahon \& Galloway (Chapter 11) }\end{array}$ \\
\hline $\begin{array}{l}\text { Practice } \\
\text { traditions }\end{array}$ & $\begin{array}{l}\text { Practice traditions carry the imprints of prior } \\
\text { sayings, doings, and ways of relating enacted } \\
\text { in a practice. They "encapsulate the history of }\end{array}$ & $\begin{array}{l}\text { Wilkinson (Chapter 10) } \\
\text { Mahon \& Galloway (Chapter 11) } \\
\text { Pennanen et al. (Chapter 12) }\end{array}$ \\
\hline
\end{tabular}




\begin{tabular}{|c|c|c|}
\hline & $\begin{array}{l}\text { the happenings of the practice ... and act as a } \\
\text { kind of collective 'memory' of the practice" } \\
\text { (Kemmis, Wilkinson et al. 2014, p. 27). } \\
\text { Practice traditions are invoked in a workplace } \\
\text { when people refer to 'the way we do things } \\
\text { around here'. }\end{array}$ & \\
\hline Praxis & $\begin{array}{l}\text { Used in both a neo-Aristotelian sense to } \\
\text { denote "action that is morally-committed, and } \\
\text { oriented and informed by traditions in a field" } \\
\text { (Kemmis \& Smith, 2008, p. 4) and in a post } \\
\text { Hegelian and post Marxian sense to denote } \\
\text { "history making action" (Kemmis, 2010a, p. } \\
\text { 9). }\end{array}$ & $\begin{array}{l}\text { Wilkinson (Chapter 10) } \\
\text { Mahon \& Galloway (Chapter 11) } \\
\text { Green et al. (Chapter 7) }\end{array}$ \\
\hline $\begin{array}{l}\text { Project (as in the } \\
\text { project of a } \\
\text { practice) }\end{array}$ & $\begin{array}{l}\text { Encompasses (a) the intention (aim) that } \\
\text { motivates the practice, (b) the actions } \\
\text { (interconnected sayings, doings and relatings) } \\
\text { undertaken in the conduct of the practice, and } \\
\text { (c) the ends the actor aims to achieve through } \\
\text { the practice (although it might turn out that } \\
\text { these ends are not attained) (Rönnerman \& } \\
\text { Kemmis, in press). } \\
\text { Akin to Schatzki's (2002) concept of } \\
\text { 'teleoaffective structure'. }\end{array}$ & $\begin{array}{l}\text { Sjølie (Chapter 3) } \\
\text { Hopwood (Chapter 4) } \\
\text { Green et al. (Chapter 7) } \\
\text { Langelotz (Chapter 8) } \\
\text { Wilkinson (Chapter 10) - elaborates } \\
\text { with reference to telos and aim }\end{array}$ \\
\hline $\begin{array}{l}\text { Sayings, doings, } \\
\text { and relatings }\end{array}$ & $\begin{array}{l}\text { The actions of which practices are comprised. } \\
\text { Sayings (which include thinkings) include } \\
\text { utterances and forms of understandings; } \\
\text { doings include physical actions; and relatings } \\
\text { include ways in which people relate to one } \\
\text { another and the world. In practices, sayings, } \\
\text { doings, and relatings are always bundled } \\
\text { together. }\end{array}$ & $\begin{array}{l}\text { Salamon (Chapter 5) - problematises } \\
\text { infants' sayings } \\
\text { Edwards-Groves \& Grootenboer } \\
\text { (Chapter 2) - spotlights relatings }\end{array}$ \\
\hline Site & $\begin{array}{l}\text { Following Schatzki (2003), the site of a } \\
\text { practice is "that realm or set of phenomena (if } \\
\text { any) of which it is intrinsically a part" (p. } \\
176) \text {. }\end{array}$ & $\begin{array}{l}\text { Edwards-Groves \& Grootenboer } \\
\text { (Chapter 2) } \\
\text { Pennanen et al. (Chapter 12) }\end{array}$ \\
\hline $\begin{array}{l}\text { Stirred into } \\
\text { practices/learning }\end{array}$ & $\begin{array}{l}\text { The notion of being 'stirred in' is intended to } \\
\text { capture how people are initiated into } \\
\text { practices, in other words, how they learn to go } \\
\text { on in a practice. This is described in terms of } \\
\text { people being be stirred into the sayings, } \\
\text { doings and ways of relating that comprise a } \\
\text { practice. }\end{array}$ & $\begin{array}{l}\text { Edwards-Groves \& Grootenboer } \\
\text { (Chapter 3) } \\
\text { Sjølie (Chapter 3) } \\
\text { Langelotz (Chapter 8) }\end{array}$ \\
\hline
\end{tabular}

Note. We present this table in the knowledge that definitions can sometimes be problematic. We do so in the pursuit of clarity, not to imply or encourage rigidity in their use. Some of the terms in this table are in common usage, but have been included because of their distinctive use in the theory of practice architectures.

\section{Acknowledgements}

We are very grateful to the reviewers of this chapter - especially Hannu Heikkinen, Christine Edwards-Groves, Nick Hopwood, Nicole Mockler, Kiprono Langat, and Jane Wilkinson - all of whom have been invaluable critical friends in the drafting of this chapter. We would also like to thank Lill Langelotz who shared a draft of the chapter with Swedish colleagues at a practice symposium hosted by the University of Borås, and to acknowledge the symposium audience members for their helpful feedback. We are grateful, too, to the authors of other chapters in this volume who participated in discussions and debates about the ideas presented in this chapter. 


\section{References}

Bourdieu, P. (1977). Outline of a theory of practice (R. Nice, Trans.). Cambridge, UK: Cambridge University Press.

Bourdieu, P. (1990). The logic of practice (R. Nice, Trans.). Stanford, CA: Stanford University Press.

Bourdieu, P., \& Wacquant, L. (1992). An invitation to reflexive sociology. Chicago, IL: University of Chicago Press.

Brennan Kemmis, R., \& Green, A. (2013). Vocational education and training teachers' conceptions of their pedagogy. International Journal of Training Research, 11(2), 101-121.

Bristol, L. (2014). Leading-for-inclusion: Transforming action through teacher talk. International Journal of Inclusive Education. doi:10.1080/13603116.2014.971078

Butler, C., Parkhill, K., \& Pidgeon, N. (2014). Energy consumption and everyday life: Choice, values and agency through a practice theoretical lens. Journal of Consumer Culture. doi:10.1177/1469540514553691

Capra, F. (1997). The web of life. New York, NY: Anchor.

Capra, F. (2004). The hidden connections: A science for sustainable living. New York, NY: Anchor.

Capra, F. (2005). Speaking nature's language: Principles for sustainability. In M. K. Stone \& Z. Barlow (Eds.), Ecological literacy: Educating our children for a sustainable world (pp. 1829). San Francisco, CA: Sierra Book Club Books.

Corradi, G., Gherardi, S., \& Verzelloni, L. (2010). Through the practice lens: Where is the bandwagon of practice-based studies heading? Management Learning, 41, 265-283. doi:10.1177/1350507609356938

Edwards-Groves, C., \& Rönnerman, K. (2012). Generating leading practices through professional learning. Professional Development in Education. doi:10.1080/19415257.2012.724439

Engeström, Y. (1999). Activity theory and individual and social transformation. In Y. Engeström, R. Miettinen, \& R. L. Punamäki (Eds.), Perspectives on activity theory (pp. 19-38). Cambridge, UK: Cambridge University Press.

Feldman, M. S., \& Orlikowski, W. J. (2011). Theorizing practice and practicing theory. Organization Science, 22(5). doi:10.1287/orsc.1100.0612

Fenwick, T. (2010). Rethinking the "thing": Sociomaterial approaches to understanding and researching learning in work. Journal of Workplace Learning, 22(1/2), 104-116. doi:10.1108/13665621011012898

Fenwick, T. (2012). Co-production in practice: A sociomaterial analysis. Professions and Professionalism, 2(2), 1-16. doi:10.7577/pp/v2i1.323

Foucault, M. (1976). The archaeology of knowledge (A. M. Sheridan Smith, Trans.). New York, NY: Harper and Row.

Foucault, M. (1980). Power/knowledge: Selected interviews and other writings. New York, NY: Pantheon.

Garfinkel, H. (1967). Studies in ethnomethodology. Englewood Cliffs, NJ: Prentice-Hall.

Gherardi, S. (2006). Organisational knowledge: The texture of workplace learning. Malden, MA: Blackwell.

Gherardi, S. (2009). Introduction: The critical power of the 'practice lens'. Management Learning, 40, 115-128. doi:10.1177/1350507608101225

Gherardi, S., \& Nicolini, D. (2000a). The organizational learning of safety in communities of practice. Journal of Management Inquiry, 9(1), 7-18.

Gherardi, S., \& Nicolini, D. (2000b). To transfer is to transform: The circulation of safety knowledge. Organization, 7(2), 329-348.

Giddens, A. (1976). New rules of sociological method. London: Hutchinson.

Giddens, A. (1979). Central problems in social theory. Basingstoke, UK: Macmillan.

Giddens, A. (1984). The constitution of society: Outline of the theory of structuration. Berkeley, CA: University of California Press.

Green, B. (2009). Introduction. In B. Green (Ed.), Understanding and researching professional practice (pp. 1-18). Rotterdam, Netherlands: Sense. 
Green, B., \& Hopwood, N. (2015). The body in professional practice, learning and education: A question of corporeality. In B. Green \& N. Hopwood (Eds.), The body in professional practice, learning and education: Body/practice (pp. 15-33). London: Springer.

Green, W., Hibbons, R., Houghton, L., \& Ruutz, A. (2013). Reviving praxis: Stories of continual professional learning and practice architectures in a faculty-based teaching community of practice. Oxford Review of Education, 39(2), 247-266.

Habermas, J. (1972). Knowledge and human interests (J. J. Shapiro, Trans.). London, UK: Heinemman.

Habermas, J. (1974). Theory and practice (J. Viertel, Trans.). London, UK: Heinemann.

Hager, P. (2012). Theories of practice and their connections with learning: A continuum of more and less inclusive accounts. In P. Hager, A. Lee, \& A. Reich (Eds.), Practice, learning and change: Practice-theory perspectives on professional learning (pp. 17-32). Dordrecht, Netherlands: Springer.

Hager, P. (2013). Practice and Group Learning. Educational Philosophy and Theory. doi:10.1080/00131857.2013.779212

Hager, P., Lee, A., \& Reich, A. (2012). Problematising practice, reconceptualising learning and imagining change. In P. L. Hager, A. Lee, \& A. Reich (Eds.), Practice, learning and change: Practice-theory perspectives on professional learning (pp. 1-14). Dordrecht, Netherlands: Springer.

Hardy, I. (2010a). Academic architectures: Academic perceptions of teaching conditions in an Australian university. Studies in Higher Education, 35(4), 391-404.

Hardy, I. (2010b). Teacher talk: Flexible delivery and academics' praxis in an Australian university. International Journal for Academic Development, 15(2), 131-142.

Hargreaves, T. (2011). Practice-ing behaviour change: Applying social practice theory to proenvironmental behaviour change. Journal of Consumer Culture, 1, 79-99. doi: $10.1177 / 1469540510390500$

Heidegger, M. (1962). Being and time (J. Macquarrie \& E. Robinson, Trans.). New York, NY: Harper and Row.

Hemmings, B., Kemmis, S., \& Reupert, A. (2013). Practice architectures of inclusive education teaching in Australia. Professional Development in Education, 39(4). doi:10.1080/19415257.2013.796293

Hodder, I. (2012). Entangled: An archaeology of the relationships between human beings and things. New York, NY: John Wiley.

Hopwood, N. (2014). A socio-material account of signatures, partnerships and accountabilities in practice. Professions and Professionalism, 4(2). doi:10.7577/pp.604

Hopwood, N., Fowler, C., Lee, A., Rossiter, C., \& Bigsby, M. (2013). Understanding partnership practice in child and family nursing through the concept of practice architectures. Nursing Inquiry. doi:10.1111/nin/12019

Kemmis, S. (2005). Knowing practice: Searching for saliences. Pedagogy, Culture and Society, 13(3), 391-426.

Kemmis, S. (2009). Understanding professional practice: A synoptic framework. In B. Green (Ed.), Understanding and researching professional practice (pp. 19-38). Rotterdam, Netherlands: Sense.

Kemmis, S. (2010a). Research for praxis: Knowing doing. Pedagogy, Culture and Society, 8(1), 9-27.

Kemmis, S. (2010b). What is professional practice? Recognising and respecting diversity in understandings of practice. In C. Kanes (Ed.), Elaborating professionalism: Studies in practice and theory (pp. 139-166). London, UK: Springer.

Kemmis, S., \& Brennan Kemmis, R. (2014, April). VET [Vocational Education and Training] practices and practice architectures. Paper presented at the Annual Conference of the Australian Vocational Education and Training Research Association (AVETRA), Surfers Paradise, Queensland, Australia.

Kemmis, S., Edwards-Groves, C., Wilkinson, J., \& Hardy, I. (2012). Ecologies of practices. In P. Hager, A. Lee, \& A. Reich (Eds.), Practice, learning and change: Practice-theory perspectives on professional learning (pp. 33-49). Dordrecht, Netherlands: Springer. 
Kemmis, S., \& Grootenboer, P. (2008). Situating praxis in practice: Practice architectures and the cultural, social and material conditions for practice. In S. Kemmis \& T. Smith (Eds.), Enabling praxis: Challenges for education (pp. 37-62). Rotterdam, Netherlands: Sense.

Kemmis, S., \& Heikkinen, H. (2012). Future perspectives: Peer-group mentoring and international practices for teacher development. In H. Heikkinen, H. Jokinen, \& P. Tynjälä (Eds.) Peergroup mentoring for teacher development (pp. 144-170). Milton Park: Routledge,

Kemmis, S., Heikkinen, H., Aspfors, J., Fransson, G., \& Edwards-Groves, C. (2014). Mentoring as contested practice: Support, supervision and collaborative self-development. Teaching and Teacher Education 43, 154-164.

Kemmis, S. \& Mutton, R. (2012). Education for sustainability (EfS): Practice and practice architectures. Environmental Education Research, 18(2), 187-207. doi:10.1080/13504622.2011.596929

Kemmis, S., \& Smith, T. (2008). Praxis and praxis development. In S. Kemmis \& T. Smith (Eds.), Enabling praxis: Challenges for education (pp. 3-13). Rotterdam, Netherlands: Sense.

Kemmis, S., \& Smith, T. J. (Eds.). (2008). Enabling praxis: Challenges for education. Rotterdam, Netherlands: Sense.

Kemmis, S., Wilkinson, J., Edwards-Groves, C., Hardy, I., Grootenboer, P., \& Bristol, L. (2014). Changing practices, changing education. Singapore: Springer.

Latour, B. (1996). On actor-network theory: A few clarifications. Soziale Welt, 47, 369-382.

Latour, B. (2005). Reassembling the social: An introduction to actor-network-theory. Oxford, UK: Oxford University Press.

Lave, J., \& Wenger, E. (1991). Situated learning: Legitimate peripheral participation. Cambridge, UK: Cambridge University Press.

Lloyd, A. (2010). Framing information literacy as information practice: Site ontology and practice theory. Journal of Documentation, 66(2), 245-258.

MacIntyre, A. (1981). After virtue: A study in moral theory. Notre Dame, IN: University of Notre Dame Press.

Marx, K. (1845). Theses on Feuerbach. Retrieved from https://www.marxists.org/archive/marx/works/1845/theses/theses.htm

Marx, K. (1852). The eighteenth brumaire of Louis Boneparte. Retrieved from https://www.marxists.org/archive/marx/works/1852/18th-brumaire/

Mahon, K. (2014). Critical pedagogical praxis in higher education (Unpublished doctoral dissertation), Charles Sturt University, Australia.

Nicolini, D. (2011). Practice as the site of knowing: Insights from the field of telemedicine. Organization Science. 22(3), 602-620.

Nicolini, D. (2013). Practice theory, work, and organisation: An introduction. Oxford, UK: Oxford University Press.

Nicolini, D., Gherardi, S., \& Yanow, D. (Eds). (2003). Knowing in organizations: A practice-based approach. Armonk, NY: M. E. Sharpe.

Orlikowski, W. J. (2007). Sociomaterial practices: Exploring technology at work, Organization Studies, 28, 1435-1448.

Orlkowski, W. J. (2010). Practice in research phenomena, perspective and philosophy. In D. Golsorkhi, L. Rouleau, D. Seidl, \& E. Vaara (Eds.), Cambridge handbook of strategy as practice (pp. 23-33). Cambridge, UK: Cambridge University Press.

Price, O., Sheeres, H., \& Boud, D. (2009). Remaking jobs: Enacting and learning work practices. Vocations and Learning, 2, 217-234.

Reckwitz, (2002). Toward a theory of social practices: A development in culturalist theorizing. European Journal of Social Theory, 5(2), 243-263.

Rönnerman, K., \& Kemmis, S. (in press). Stirring doctoral candidates into academic practices: A doctoral course and its practice architectures. Education Inquiry. Accepted for publication September 18, 2015.

Salamon, A., Sumsion, J., Press, F., \& Harrison, L. (2015). Implicit theories and naïve beliefs: Using the theory of practice architectures to deconstruct the practices of early childhood educators. Journal of Early Childhood Research. doi:10.1177/1476718X14563857 
Salo, P., Nylund, J., \& Stjernstrøm, E. (2014). On the practice architectures of instructional leadership. Educational Management Administration Leadership. doi: $10.1177 / 1741143214523010$

Schatzki, T. (1996). Social practices: A Wittgensteinian approach to human activity and the social. New York, NY: Cambridge University Press.

Schatzki, T. (2001). Introduction: Practice theory. In T. Schatzki, K. Knorr Cetina, \& E. von Savigny (Eds.), The practice turn in contemporary theory (pp. 1-14). London: Routledge.

Schatzki, T. (2002). The site of the social: A philosophical account of the constitution of social life and change. University Park, PA: The Pennsylvania State University Press.

Schatzki, T. (2003). A new societist social ontology. Philosophy of the Social Sciences, 33(2), 174202.

Schatzki, T. (2005). Peripheral vision: The sites of organizations. Organization Studies, 26(3), 465484.

Schatzki, T. (2006). On organizations as they happen. Organization Studies, 27, 18631873. doi: $10.1177 / 0170840606071942$

Schatzki, T. (2010). The timespace of human activity: On performance, society, and history as indeterminate teleological events. Lanham, MD: Lexington.

Schatzki, T. (2012). A primer on practices: Theory and research. In J. Higgs (Ed.), Practice-based education: Perspectives and strategies (pp. 13-26). Rotterdam, Netherlands: Sense.

Shove, E., Pantzar, M., \& Watson, M. (2012). The dynamics of social practices: Everyday life and how it changes. Thousand Oaks, CA: Sage

Sjølie, E. (2014). Pedagogy is just common sense: A case study of student teachers' learning practices (Doctoral dissertation), Norwegian University of Science and Technology, Norway.

Swidler, A. (2001). What anchors cultural practices. In T. Schatzki, K. Knorr Cetina, \& E. von Savigny (Eds.), The practice turn in contemporary theory (pp. 74-92). London: Routledge.

Taylor, Charles. (1985). Philosophy and the human sciences: Philosophical papers 2. Cambridge, UK: Cambridge University Press.

Taylor, Carol. (2012). Student engagement, practice architectures and phronesis in the student transitions and experiences project. Journal of Applied Research in Higher Education, 4(2), 109-125.

Wilkinson, J., Olin, A., Lund, T., Ahlberg, A., \& Nyvaller, M. (2010). Leading praxis: Exploring educational leadership through the lens of practice architectures. Pedagogy, Culture and Society, 18(1), 67-79.

Wittgenstein, L. (1957). Philosophical investigations (3 $3^{\text {rd }}$ ed.) (G. E. M. Anscombe, Trans.). New York, NY: Macmillan.

\section{Affiliations}

Kathleen Mahon (Corresponding author)

Research Institute for Professional Practice, Learning and Education (RIPPLE)

Charles Sturt University, Wagga Wagga, Australia

Email correspondence: kathleen.a.mahon@gmail.com

Stephen Kemmis

Research Institute for Professional Learning, Practice and Education (RIPPLE)

Charles Sturt University, Wagga Wagga, Australia

Susanne Francisco

School of Education

Charles Sturt University, Wagga Wagga, Australia

and

University of Technology, Sydney 
Annemaree Lloyd

Swedish School of Library and Information Science

University of Borås, Sweden 